\title{
Plant growth regulator effects on sunflower parents and $\mathrm{F}_{1}$ hybrids
}

\section{Dmytro Chuiko}

Kharkiv National Agrarian University

named after V.V. Dokuchaev,

Dokuchaievske-2,

Kharkivskyi Raion,

Kharkivska Oblast,

62483, Ukraine

Email:chuiko93ua@gmail.com
The need for augmented sunflower production requires finding new methods and improving existing cultivation technologies to increase performance and resistance to stresses. The low performance of breeding and seed production lines is among obstacles to the rapid introduction of new and modern sunflower hybrids into production. The study purpose was to evaluate the individual responses of self-pollinating sunflower lines intended for breeding and seed production and of $\mathrm{F}_{1}$ hybrids, which were developed by crossing these lines, to plant growth regulators. It was found that the CMS-based lines had better yield elements and oil content in response to growth regulators compared to the lines based on normal cytoplasm. The plant growth regulators increased the heterosis effect in the experimental hybrids. The best response was observed in the threeline hybrid Skh808A/Kh1002B $\times$ Kh785V for all the studied parameters. The growth regulators strengthened a correlation between the 1000-seed weight and yield $(r=0.51-0.97)$. The oil content in seeds of $\mathrm{F}_{1}$ hybrids depended on the genotype and could be comparable both with the parent with a low content of oil and with the high-oil parent. Variations in the oil content in seeds depended on the type of growth regulator and soil/climatic conditions during the seed filling.

Keywords: breeding, hybrids, lines, plant growth regulators, seed production, sunflower

\section{INTRODUCTION}

For more than 100 years, the heterosis effect has benefitted agriculture, demonstrating the advantages of $\mathrm{F}_{1}$ hybrids over their parents (Patrick, 2013). After the discovery of heterosis in sunflower breeding, the cultivation of varietiespopulations becomes unprofitable in agriculture. The sown areas under sunflower varieties began to gradually decrease, they were replaced by more high-yielding, resistant to pests and weather conditions, morphologically stable, heterotic hybrids. In the world, over $65 \%$ of crops are represented by hybrids, and the gain in the yield capacity from growing hybrids amounts to $50 \%$ (Lippman et al., 2007).
Due to heterosis, genes that reduce the plant viability transit to a recessive state in F1 hybrids (Lynch, 1997). Gustafsson (1946) distinguishes three types of heterosis: reproductive, somatic and adaptive.

The basis of sunflower hybrids grown in Ukraine and Europe are hybrid combinations obtained by crossing two homozygous lines (interline), variety with line (variety-line) and multiline hybrids obtained via backcrossing (Kyrychenko et al., 2010). They are created from parental lines generated through repeated inbreeding to the complete homozygotization of plants.

However, sunflower inbreeding (self-pollination) is associated with expression of undesirable traits, both for breeding and for seed production. 
The performance decrease, growth and development retardation of self-pollinating lines are major disadvantages (Skvortsov, 2006). The hybrid sunflower seed production depends on parental lines that are characterized by low seed productivity resulted from inbreeding depression (Matvienko, 1992). Academician Kyrychenko (2005) noted that the inbreeding depression was weak in I1-I2 generations, and each subsequent self-pollination of the line led to a greater inbreeding depression. The greatest effects of lethal genes in sunflower lines are observed in I5-I6 generations, which become completely homozygous in I8-I10 generations, reaching the inbred minimum.

The weather instability in recent decades makes breeders find ways to increase the yield capacity of sunflower parents in the shortest possible time. In this context, it is advisable to use plant growth regulators as a mechanism to reduce depression in self-pollinating sunflower lines and to augment their adaptation to stresses.

Plant growth regulators are organic substances, low concentrations of which alter physiological functions occurring in the plant (Szweykowska, 1997). The affected processes concern mainly the plant growth and development as well as the biochemical composition (Davies, 2010). Plant growth regulators can be grouped into growth stimulants and inhibitors. Plant growth stimulants are a group of natural hormones: auxins, gibberellins and cytokinins. Abscisic acid and ethylene are growth inhibitors (Geetha et al., 2017).

The advantage of using plant growth regulators is their ability to increase the efficiency of plant nutrient utilization and maximize the fulfillment of genetic and physiological potentials (Jung et al., 2018), being non-toxic to plants and the environment and neutralizing the effects of heavy metals in soil (Gruznova, 2018). Growth regulators are responsible for important processes in the plant, boosting the resistance to abiotic stresses and stimulating the growth and development (Upreti et al., 2016).

Applications of agents containing humic substances such as fulvic acids and potassium lignohumate can increase the plant's absorption of micronutrients from soil (Marenych, 2018), improve the quality and productivity of seeds (Knapowski, 2015).
Currently, synthetic and natural growth regulators are used in the world. Natural regulators include different strains of fungi, extracts from leaves or other vegetative organs of the plant, different species of bacteria, etc. Their application leads to an increase in the plant dry weight, performance, 1000-seed weight, and resistance to phytopathogens, as confirmed by experiments on different crops (Ousley et al., 1994; Lucy, 2004; Bernard et al., 1997; Iqbal et al., 2019).

Studies of the growth regulator effects on useful agricultural characteristics of sunflower and other crops have been conducted since the middle of the 20th, when the first phytohormones of plants were discovered. However, there have been few studies with growth regulators in sunflower breeding and seed production. Therefore, the study purpose was to investigate the responses of different sunflower genotypes represented by self-pollinating lines and experimental hybrids originated from these lines in the Eastern Forest-Steppe of Ukraine.

\section{MATERIALS AND METHODS}

The field experiments were carried out in the experimental field of Kharkiv National Agrarian University named after VV Dokuchaiev (Chair of Genetics, Breeding and Seed Production).

Lines bred at the Plant Production Institute named after VYa Yuriev of NAAS of Ukraine and the confectionery variety Shchelkunchyk (TOV Driada, Ukraine) were taken as test material and as starting material for generating experimental hybrids. Self-pollinating lines were pollen fertility restorers $\mathrm{Kh} 06135 \mathrm{~V}$ and $\mathrm{Kh} 785 \mathrm{~V}$, lines - sterile analogues Skh1002A, Skh808A and Skh1012A and its fertile analogue - line Kh1012B, as well as simple hybrid - sterile female component Skh808A/Kh1002B. Sunflower seeds were sown on 7 May 2018 and 9 May 2019. No supplementary fertilizers were applied. Soil herbicide (acetochlor, $900 \mathrm{~g} / \mathrm{L}$ ) was applied at a dose of 2.53.0 L/ha two weeks prior to the sunflower sowing in compliance with the technological procedures for the experimental fields.

Growth regulators FULVITAL Plus, EcoStim and QuadroStim were applied on sunflower selfpollinating lines and experimental hybrids by repeated spraying during the growing period in 
the '2-5 true leaves' and 'flower-bud formation' phases when the temperature ranged from 10 to $18^{\circ} \mathrm{C}$.

FULVITAL PLUS (150 g/ha dose) is a watersoluble agent, containing fulvic salts, micronutrients, and easily digestible natural organic sulfur (MSM).

EcoStim ( $25 \mathrm{~mL} /$ ha dose) has active substances as an aqueous-alcoholic solution of metabolites from the strain of a symbiotic endophyte fungus living on Panax ginseng M., isolated from ginseng roots.

QuadroStim (500 mL/ha dose) consists of four groups of organic compounds, namely: polyethylene oxide (400 and 1500), arachidonic acid, succinic acid and potassium lignohumate.

Crossing was performed by manual transfer of pollen from the parent to the sterile analogue of a self-pollinating line, with preliminary isolation of plants under agrofiber bags the day before anthesis. Of the combinations, five hybrid combinations with the largest numbers of set seeds were selected: Skh1002A $\times$ Kh1012B, Skh1012A $\times$ Kh06135V, Skh808A/Kh1002B × Kh06135V, Skh808A/Kh1002B $\times$ Kh785V and Skh808A $\times$ Shchelkunchyk.

The plots were arranged in a systematic sequence with 4 replications according to conventional methods (Ermantraut, 2014); the plot area was $16.8 \mathrm{~m}^{2}$; the sowing design was $70 \times 25$; the forecrop was winter wheat; the plant density was 57.000/ha. Observations and measurements were performed on day 30 after anthesis; the seed productivity and oil content were determined when seeds reached complete biological maturity. The oil content was determined by nuclear magnetic resonance in the Laboratory of Genetics, Biotechnology and Quality of the Plant Production Institute named after VYa Yuriev of NAAS of Ukraine.

Data were statistically processed, as Goptsiy (2003) described, using Microsoft Office Excel 2010 and Statistica 10. Statistical significance of the results was checked with LSD.

In 2018, the amount of precipitation was sufficient during the 'sowing-emergence' period $(15.9 \mathrm{~mm})$; the precipitation was moderate during the 'emergence-anthesis' period $(43.5 \mathrm{~mm})$; and there was no precipitation at all during the seed ripening in July-August. The temperature during the growing period was by $3.9^{\circ} \mathrm{C}$ higher than the multi-year average $\left(18.6^{\circ} \mathrm{C}\right)$.

In 2019 , the temperature was high (the average temperature during the growing period was $20.8^{\circ} \mathrm{C}$, which is by $2.2^{\circ} \mathrm{C}$ higher than the multiyear average), and the drought was severe during the sunflower anthesis (the average rainfall during the growing period was $107.7 \mathrm{~mm}$ ), with the multi-year average of $271.4 \mathrm{~mm}$. The hydrothermal coefficient (HTC) during the growing period was 0.9 in 2018 and 1.0 in 2019, which indicates a water deficit supply during this period (Figs. 1, 2). The soil in the experimental field is Calcic Voronic Chernozem CL UE1.

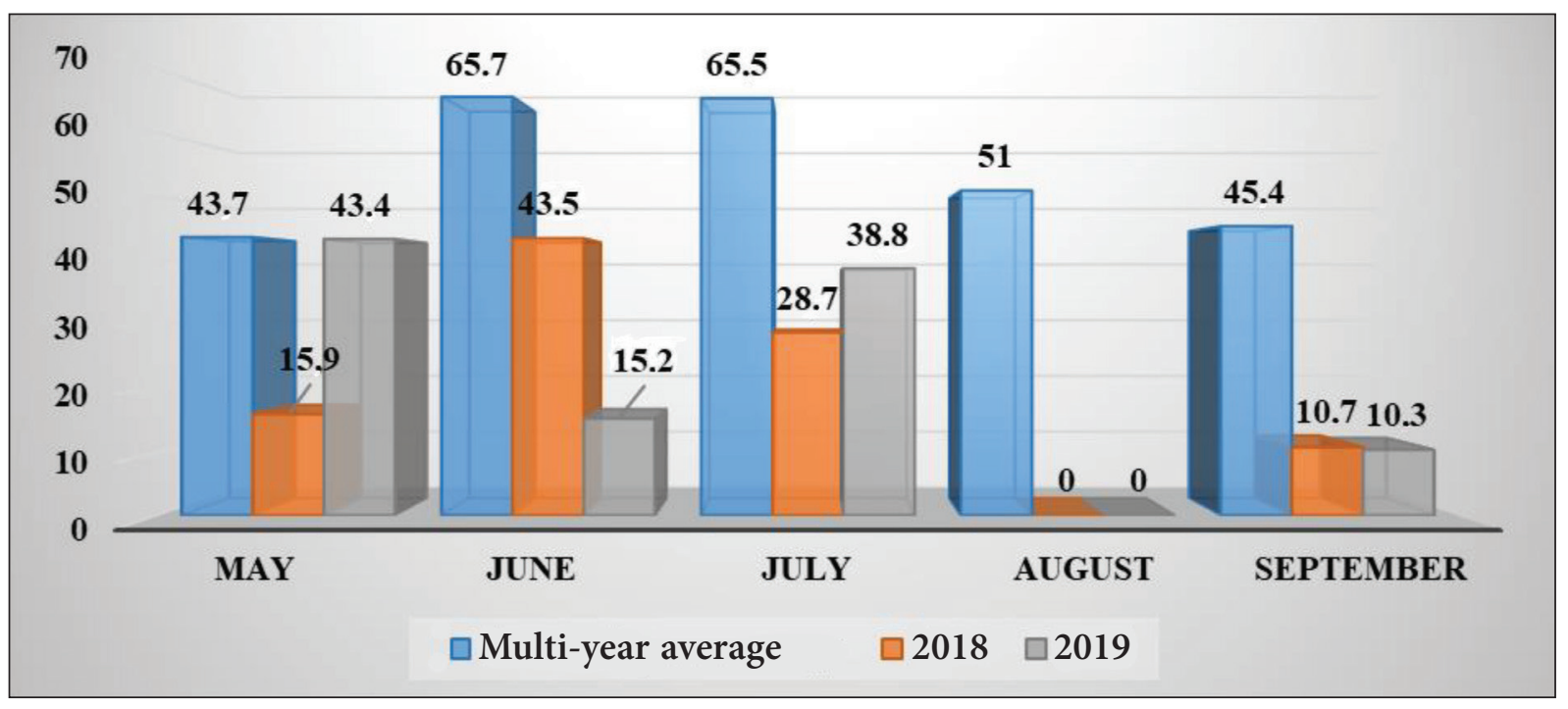

Fig. 1. The average precipitation amount in the study years compared to the multi-year average, $\mathrm{mm}$ 


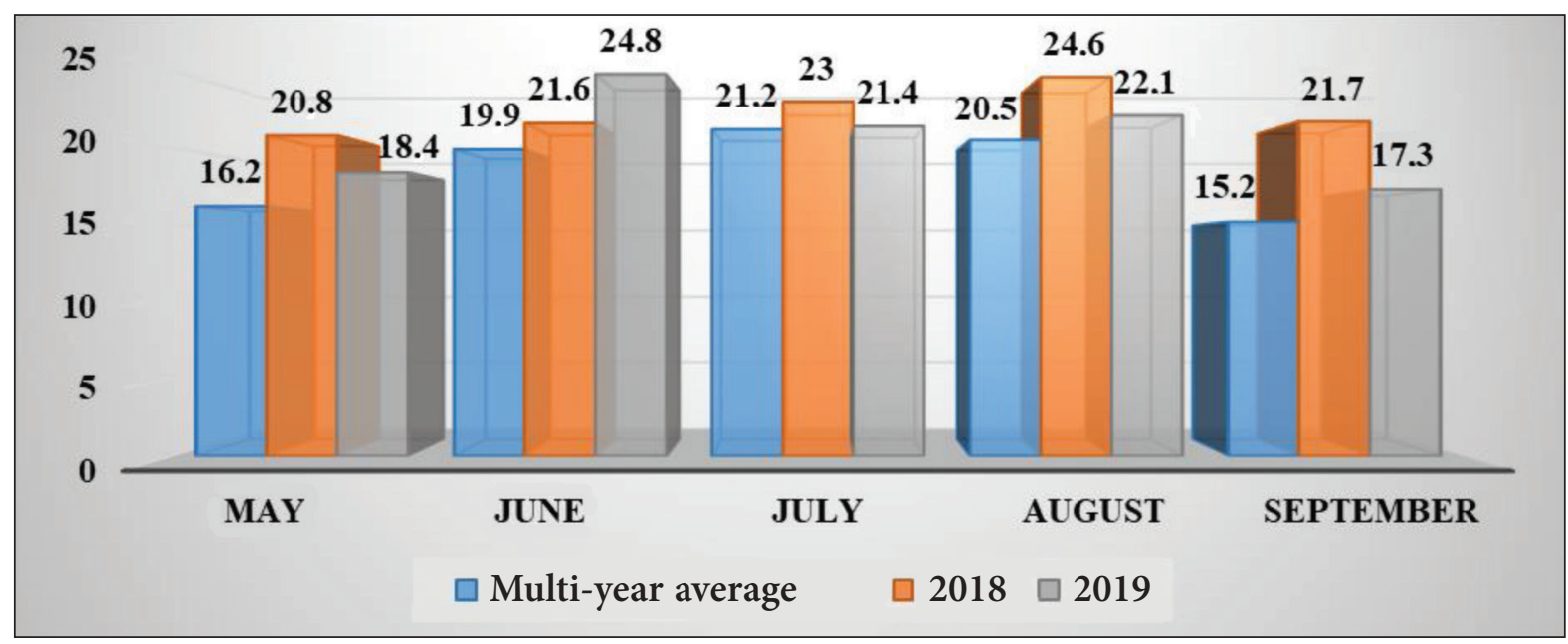

Fig. 2. The temperature during the growing period compared to the multi-year average, ${ }^{\circ} \mathrm{C}$

\section{RESULTS AND DISCUSSION}

The main economic characteristic of any crop is its yield. It is influenced by a number of biotic and abiotic factors, which determine the plant performance parameters. Properly selected growth regulators can reduce the use of pesticides, which in turn will improve the ecological condition of the environment.

The three-line hybrid Skh808A/Kh1002B $\times$ Kh785V had the best response to FULVITAL Plus, EcoStim and QuadroStim: the gain in the yield varied within $0.3-0.7$ tha $^{-1}$ (11.1-22.6\%), depending on the growth regulator used. The hybrid parents had specific responses to the growth regulators. Thus, the female component Skh808A/ Kh1002B responded positively only to FULVITAL Plus $\left(2.9\right.$ tha $\left.^{-1}\right)$, with a gain of 0.3 tha $^{-1}$ (10.3\%), compared to the control $\left(2.6\right.$ tha $\left.^{-1}\right)$. The male component of this hybrid, line Kh785V, gave the average gain across the study years of 0.3 tha $^{-1}(17.7 \%)$ under influence of FULVITAL Plus and EcoStim. Shapoval (2014) points out that the mechanism of action of EcoStim, like of other symbiotic fungi-based agents, consists in increasing the cell permeability, reducing the nutrient transport-related expenditure by plants and boosting the photosynthetic activity.

QuadroStim did not have a positive effect on the yields from four of the five studied hybrid combinations, Skh808A/Kh1002B $\times$ Kh06135V, Skh1002A $\times$ Kh1012B, Skh1012A $\times$ Kh06135V, Skh808A $\times$ Shchelkunchyk, as their yields were similar to the control or even lower. Of the parents, the yields decreased in the lines Skh808A/ Kh1002B $\left(-0.2\right.$ tha $\left.^{-1}\right), \operatorname{Kh} 785 \mathrm{~V}\left(-0.2\right.$ tha $\left.^{-1}\right)$ and variety Shchelkunchyk $\left(-1.1\right.$ tha $\left.^{-1}\right)$. QuadroStim increased the parents' yields in a range of 7.7$16.2 \%$, depending on the line under investigation (Table 1).

FULVITAL Plus was the most effective. It increased the yields from all the hybrid combinations and their parents, except for Shchelkunchyk, the yield of which did not differ from the control $\left(5.8\right.$ tha $\left.^{-1}\right)$. Shchelkunchyk gave a decreased yield when treated by any treated growth regulator, which may be due to its genetic peculiarities.

Dehodiuk et al. (2014) noted that spraying with fulvic acids that are ingredients of FULVITAL Plus during the vegetation period was more rational due to the fact that fulvic acid has a lower molecular weight and is more biologically active compared to other humates. This can describe the more positive effect of FULVITAL Plus on sunflower yields. One should also remember that the yield response to any agent or technological procedure directly depends on the plant genotype (Kyrychenko, 2005).

It is known that the 1000 -seed weight is inherited in $\mathrm{F}_{1}$ hybrids by intermediate type with the dominance of the best parent, or the effect of true heterosis in plants is detected and depends on cultivation conditions (Škorić, 2015). It characterizes the sowing qualities of seeds, their plumpness, viability, marketable and breeding parameters of hybrids, and their seed productivity. 
Table 1. Yields of experimental hybrids and their parents, depending on the plant growth regulator $\left(\right.$ tha $\left.^{-1}\right)$, 2018-2019

\begin{tabular}{|c|c|c|c|c|c|c|}
\hline \multirow{2}{*}{ Treatment $(\mathrm{B})^{\star *}$} & \multicolumn{2}{|c|}{$\operatorname{Hybrid}(\mathrm{A})^{*}$} & \multicolumn{2}{|c|}{ Female component ${ }^{*}$} & \multicolumn{2}{|c|}{ Male component ${ }^{\star}$} \\
\hline & tha $a^{-1}$ & $\%$ & tha $^{-1}$ & $\%$ & tha $^{-1}$ & $\%$ \\
\hline & \multicolumn{2}{|c|}{ Skh808A/Kh1002B $\times$ Kh06135V } & \multicolumn{2}{|c|}{ Skh808A/Kh1002B } & \multicolumn{2}{|c|}{ Kh06135V } \\
\hline Control & 2.7 & & 2.6 & & 2.1 & \\
\hline FULVITAL Plus & 3.5 & 22.9 & 2.9 & 10.3 & 2.2 & 4.5 \\
\hline EcoStim & 3.6 & 25.0 & 2.1 & -19.2 & 2.4 & 12.5 \\
\hline \multirow[t]{2}{*}{ QuadroStim } & 2.6 & -3.7 & 2.5 & -3.8 & 2.4 & 12.5 \\
\hline & \multicolumn{2}{|c|}{ Skh1002A $\times$ Kh1012B } & \multicolumn{2}{|c|}{ Skh1002A } & \multicolumn{2}{|c|}{ Kh1012B } \\
\hline Control & 1.7 & & 1.0 & & 1.1 & \\
\hline FULVITAL Plus & 2.1 & 19.0 & 1.2 & 16.6 & 1.3 & 15.4 \\
\hline EcoStim & 2.0 & 15.0 & 1.3 & 23.1 & 1.2 & 8.3 \\
\hline \multirow[t]{2}{*}{ QuadroStim } & 1.7 & 0 & 1.1 & 9.1 & 1.3 & 15.4 \\
\hline & \multicolumn{2}{|c|}{ Skh808A/Kh1002B $\times$ Kh785V } & \multicolumn{2}{|c|}{ Skh808A/Kh1002B } & \multicolumn{2}{|c|}{ Kh785V } \\
\hline Control & 2.4 & & 2.6 & & 1.5 & \\
\hline FULVITAL Plus & 2.7 & 11.1 & 2.9 & 10.3 & 1.8 & 16.7 \\
\hline EcoStim & 3.0 & 20.0 & 2.1 & -19.2 & 1.8 & 16.7 \\
\hline \multirow[t]{2}{*}{ QuadroStim } & 3.1 & 22.6 & 2.5 & -3.8 & 1.3 & -13.3 \\
\hline & \multicolumn{2}{|c|}{ Skh1012A $\times$ Kh06135V } & \multicolumn{2}{|c|}{ Skh1012A } & \multicolumn{2}{|c|}{ Kh06135V } \\
\hline Control & 3.1 & & 1.2 & & 2.1 & \\
\hline FULVITAL Plus & 3.2 & 3.1 & 1.5 & 20.0 & 2.2 & 4.5 \\
\hline EcoStim & 3.1 & 0 & 1.5 & 20.0 & 2.4 & 12.5 \\
\hline \multirow[t]{2}{*}{ QuadroStim } & 2.9 & -6.4 & 1.3 & 7.7 & 2.4 & 12.5 \\
\hline & \multicolumn{2}{|c|}{ Skh808A $\times$ Shchelkunchyk } & \multicolumn{2}{|c|}{ Skh808A } & \multicolumn{2}{|c|}{ Shchelkunchyk } \\
\hline Control & 3.1 & & 3.1 & & 5.8 & \\
\hline FULVITAL Plus & 3.9 & 20.5 & 3.5 & 11.4 & 5.8 & 0 \\
\hline EcoStim & 2.8 & -9.8 & 3.8 & 18.4 & 5.5 & -5.2 \\
\hline QuadroStim & 2.9 & -6.4 & 3.7 & 16.2 & 4.8 & -17.2 \\
\hline $\mathrm{LSD}_{\mathrm{AB}}$ & 0.28 & & 1.34 & & 1.97 & \\
\hline $\mathrm{LSD}_{\mathrm{A}}$ & 0.14 & & 0.67 & & 0.98 & \\
\hline $\mathrm{LSD}_{\mathrm{B}}$ & 0.13 & & 0.67 & & 0.98 & \\
\hline
\end{tabular}

${ }^{\star}$ Factor A, ${ }^{* \star}$ Factor B; Significant at $P<0.05$.

Judging by the gain in the 1000-seed weight, Quadrostim was the most effective. Thus, in 20182019 , it on average increased the 1000-seed weight by $12.6 \mathrm{~g}$, and the 1000 -seed weight amounted to $68 \mathrm{~g}$ (control $55.4 \mathrm{~g}$ ) in the three-line hybrid Skh808A/Kh1002B $\times$ Kh785V (where the female form was a simple hybrid Skh808A/Kh1002B); by $7.1 \mathrm{~g}$ in the female form; and by $3.5 \mathrm{~g}$ in the male component. QuadroStim increased the 1000-seed weight in the female line Skh808A/Kh1002B to $56.9 \mathrm{~g}$, compared to the control of $49.8 \mathrm{~g}$; the ef- fects of FULVITAL Plus and EcoStim on this genotype were less conspicuous, or the parameter remained at the control level. FULVITAL Plus and EcoStim significantly increased the 1000seed weight in the hybrid Skh1002A $\times$ Kh1012B in a range of 51.8-51.9 $\mathrm{g}$ (control $40.2 \mathrm{~g}$ ) and its parents (Skh1002A in a range of 42.4-44.5 g (control $37.2 \mathrm{~g}$ ) and Kh1012B in a range of 37.8-40.2 $\mathrm{g}$ (control $30 \mathrm{~g}$ ) (Table 2).

There was a direct correlation between the yield and 1000-seed weight (Grabovsky, 2010) $(r \approx 0.80)$. 
Table 2. Growth regulator effects on the average 1000-seed weight in the hybrids and their parents (g), 2018-2019

\begin{tabular}{|c|c|c|c|}
\hline \multirow{2}{*}{ Treatment $(B)^{\star *}$} & Hybrid $(\mathrm{A})^{*}$ & Female component ${ }^{*}$ & Male component ${ }^{\star}$ \\
\hline & \multicolumn{3}{|c|}{ 1000-seed weight, $g$} \\
\hline & Skh808A/Kh1002B $\times$ Kh06135V & Skh808A/Kh1002B & Kh06135V \\
\hline Control & 50.1 & 49.8 & 42.9 \\
\hline FULVITAL Plus & 46.4 & 49.2 & 45.1 \\
\hline EcoStim & 50.0 & 45.0 & 47.6 \\
\hline \multirow[t]{2}{*}{ QuadroStim } & 39.8 & 56.9 & 49.7 \\
\hline & Skh1002A $\times$ Kh1012B & Skh1002A & Kh1012B \\
\hline Control & 40.2 & 37.2 & 30.0 \\
\hline FULVITAL Plus & 51.9 & 44.5 & 37.8 \\
\hline EcoStim & 51.8 & 42.4 & 40.2 \\
\hline \multirow[t]{2}{*}{ QuadroStim } & 42.8 & 37.1 & 42.1 \\
\hline & Skh808A/Kh1002B $\times$ Kh785V & Skh808A/Kh1002B & Kh785V \\
\hline Control & 55.4 & 49.8 & 43.7 \\
\hline FULVITAL Plus & 61.6 & 49.2 & 47.4 \\
\hline EcoStim & 67.6 & 45.0 & 48.9 \\
\hline \multirow[t]{2}{*}{ QuadroStim } & 68.0 & 56.9 & 47.2 \\
\hline & Skh1012A $\times$ Kh06135V & Skh1012A & Kh06135V \\
\hline Control & 58.8 & 35.7 & 42.9 \\
\hline FULVITAL Plus & 61.4 & 39.7 & 45.1 \\
\hline EcoStim & 43.5 & 40.5 & 47.6 \\
\hline \multirow[t]{2}{*}{ QuadroStim } & 55.2 & 39.8 & 49.7 \\
\hline & Skh808A $\times$ Shchelkunchyk & Skh808A & Shchelkunchyk \\
\hline Control & 75.6 & 58.2 & 112.1 \\
\hline FULVITAL Plus & 91.7 & 61.2 & 102.1 \\
\hline EcoStim & 73.2 & 65.4 & 117.6 \\
\hline QuadroStim & 80.8 & 64.9 & 108.9 \\
\hline $\mathrm{LSD}_{\mathrm{AB}}$ & 2.8 & 12.9 & 30.7 \\
\hline $\mathrm{LSD}_{\mathrm{A}}$ & 1.4 & 6.4 & 15.3 \\
\hline $\mathrm{LSD}_{\mathrm{B}}$ & 1.2 & 6.4 & 15.3 \\
\hline
\end{tabular}

${ }^{\star}$ Factor A, ${ }^{* *}$ Factor B; Significant at $P<0.05$.

The correlation analysis confirmed a relationship between these traits and its strengthening under the plant growth regulator influence $(r \approx 0.97)$. Given the previously described effects of FULVITAL Plus and EcoStim on the yield capacity and the results of correlation analysis (which indicated their relationship), we can affirm that the plant growth regulators significantly affected the two parameters.

The growth regulators significantly affected the test weight of seeds of the studied genotypes. FULVITAL Plus, EcoStim and QuadroStim in- creased the test weight in the interline hybrid Skh1002A $\times$ Kh1012B on average to $372 \pm 1.6 \mathrm{~g} / \mathrm{L}$, $381 \pm 1.8 \mathrm{~g} / \mathrm{L}$ and $361 \pm 3.7 \mathrm{~g} / \mathrm{L}$, respectively, over the study years compared to the control of $349.7 \pm 1.7 \mathrm{~g} / \mathrm{L}$. The test weight in the parent Skh1002A was increased to $277.7 \pm 1.9 \mathrm{~g} / \mathrm{L}$, $282 \pm 1.4 \mathrm{~g} / \mathrm{L}$ and $280 \pm 1.4 \mathrm{~g} / \mathrm{L}$ with FULVITAL Plus, EcoStim and QuadroStim, respectively (control $248.2 \pm 2.7 \mathrm{~g} / \mathrm{L}$ ). After the QuadroStim treatment, the test weight in the parent Kh1012B was also increased and amounted to $343.2 \pm 1.5 \mathrm{~g} / \mathrm{L}$ (control $327.2 \pm 2.1 \mathrm{~g} / \mathrm{L}$ ). 
A high test weight was recorded for the threeline hybrid Skh808A/Kh1002B × Kh06135V. The test weight of the hybrid seeds ranged within $335.2 \pm 1.5-347.5 \pm 1.7 \mathrm{~g} / \mathrm{L}$ (control $315.2 \pm 4.6 \mathrm{~g} / \mathrm{L})$, depending on the growth regulator. The female component of the simple hybrid Skh808A/Kh1002B had improved values under the influence of FULVITAL Plus $(407.5 \pm 1.9 \mathrm{~g} / \mathrm{L})$ and QuadroStim $(395.5 \pm 4.5 \mathrm{~g} / \mathrm{L})$ compared to the control of $363.5 \pm 1.7 \mathrm{~g} / \mathrm{L}$ (Table 3 ).

The test weight depends on weather conditions and cultivation technologies during the plant growth and development as well as on harvesting conditions.

In particular, the test weight of sunflower seeds strongly depends on the phosphorus consumed by the plant (Abbadi et al., 2011), and FULVITAL Plus contains phosphorus. In addition, the adaptive capacities of the plant to water deficit and high temperature are important. The published experimental data indicate that plant growth regulators contain antioxidants (arachidonic acid, succinic acid, potassium lignohumate, fulvic acids), which affect the seed plumpness, test

Table 3. Growth regulator effects on the average test weight of sunflower seeds (g/L), 2018-2019

\begin{tabular}{|c|c|c|c|}
\hline \multirow{2}{*}{ Treatment $(B)^{* *}$} & Hybrid $^{\star}$ & Female component $^{\star}$ & Male component ${ }^{*}$ \\
\hline & \multicolumn{3}{|c|}{ Test weight, g/L } \\
\hline & Skh808A/Kh1002B $\times$ Kh06135V & Skh808A/Kh1002B & Kh06135V \\
\hline Control & $315.2 \pm 4.6$ & $363.5 \pm 1.7$ & $336 \pm 2.2$ \\
\hline FULVITAL Plus & $335.2 \pm 1.5$ & $407.5 \pm 1.9$ & $339.5 \pm 1.0$ \\
\hline EcoStim & $339.7 \pm 4.9$ & $370.5 \pm 5.7$ & $351 \pm 2.2$ \\
\hline \multirow[t]{2}{*}{ QuadroStim } & $347.5 \pm 1.7$ & $395.5 \pm 4.5$ & $366 \pm 4.1$ \\
\hline & Skh1002A $\times$ Kh1012B & Skh1002A & Kh1012B \\
\hline Control & $349.7 \pm 1.7$ & $248.2 \pm 2.7$ & $327.2 \pm 2.1$ \\
\hline FULVITAL Plus & $363.5 \pm 0.6$ & $277.7 \pm 1.9$ & $335 \pm 2.0$ \\
\hline EcoStim & $381 \pm 1.8$ & $282 \pm 1.4$ & $319 \pm 5.4$ \\
\hline \multirow[t]{2}{*}{ QuadroStim } & $361 \pm 3.7$ & $280 \pm 1.4$ & $343.2 \pm 1.5$ \\
\hline & Skh808A/Kh1002B × Kh785V & Skh808A/Kh1002B & Kh785V \\
\hline Control & $357.5 \pm 0.6$ & $363.5 \pm 1.7$ & $321.2 \pm 28.1$ \\
\hline FULVITAL Plus & $372 \pm 1.6$ & $407.5 \pm 1.9$ & $324.2 \pm 3.1$ \\
\hline EcoStim & $369.2 \pm 2.7$ & $370.5 \pm 5.7$ & $326.5 \pm 1.7$ \\
\hline \multirow[t]{2}{*}{ QuadroStim } & $356 \pm 3.6$ & $395.5 \pm 4.5$ & $335.2 \pm 1.7$ \\
\hline & Skh1012A × Kh06135V & Skh1012A & Kh06135V \\
\hline Control & $340.7 \pm 5.0$ & $341.2 \pm 1.5$ & $336 \pm 2.2$ \\
\hline FULVITAL Plus & $363.7 \pm 3.5$ & $349.5 \pm 1.9$ & $339.5 \pm 1.0$ \\
\hline EcoStim & $346.7 \pm 4.6$ & $335.5 \pm 3.7$ & $351 \pm 2.2$ \\
\hline \multirow[t]{2}{*}{ QuadroStim } & $358.2 \pm 1.7$ & $351 \pm 2.4$ & $366 \pm 4.1$ \\
\hline & Skh808A $\times$ Shchelkunchyk & Skh808A & Shchelkunchyk \\
\hline Control & $353.5 \pm 3.1$ & $379.2 \pm 4.2$ & $318.2 \pm 10.4$ \\
\hline FULVITAL Plus & $368.2 \pm 3.2$ & $389.7 \pm 9.5$ & $315 \pm 19.2$ \\
\hline EcoStim & $351.7 \pm 2.9$ & $403 \pm 5.3$ & $321.2 \pm 3.4$ \\
\hline QuadroStim & $378 \pm 1.6$ & $394.7 \pm 4.3$ & $328.7 \pm 3.5$ \\
\hline $\mathrm{LSD}_{\mathrm{AB}}$ & 5.3 & 7.8 & 15.4 \\
\hline $\mathrm{LSD}_{\mathrm{A}}$ & 2.6 & 3.9 & 7.7 \\
\hline $\mathrm{LSD}_{\mathbf{B}}$ & 2.4 & 3.9 & 7.7 \\
\hline
\end{tabular}

${ }^{*}$ Factor A, ${ }^{* *}$ Factor B; Significant at $P<0.05$. 
weight and 1000-seed weight (Ousley et al., 1994; Iqbal et al., 2019).

The oil content in seeds is determined not only by the plant genotype, but also by environmental factors, such as rainfall, the sum of average temperatures and air humidity during the growing period. Petibskaya (1993) found that the average daily air humidity effect during the growing season of sunflower on the oil content in seeds is $-37.7 \%$, and the effect of the sum of average temperatures during the 'anthesis - full maturity' period accounts for $-15.8 \%$.
In our experiments, a small amount of precipitation during the 'emergence-anthesis' period or periodic absence of precipitation and high average temperature in the same period (see Figs. 1, 2) formed the conditions, under which the oil accumulated in seeds, depending on the developmental phase and soil/climatic factors during this period. An increase in the oil content after the growth regulator treatment was observed in the threeline hybrid Skh808A/Kh1002B $\times$ Kh06135V (40.3-43.0\% vs $39.9 \%$ in the control), hybrid Skh1002A $\times$ Kh1012B (46.9-48.3\% vs $45.7 \%$ in

Table 4. Growth regulator effects on the average oil content in seeds of hybrids and their parents (\%), 2018-2019

\begin{tabular}{|c|c|c|c|}
\hline \multirow{2}{*}{ Treatment $(B)^{\star *}$} & Hybrid $(\mathrm{A})^{*}$ & Female component ${ }^{*}$ & Male component ${ }^{*}$ \\
\hline & \multicolumn{3}{|c|}{ Oil content, \% } \\
\hline & Skh808A/Kh1002B $\times$ Kh06135V & Skh808A/Kh1002B & Kh06135V \\
\hline Control & 39.9 & 48.9 & 39.0 \\
\hline FULVITAL Plus & 43.0 & 48.3 & 37.8 \\
\hline EcoStim & 40.3 & 47.1 & 38.5 \\
\hline \multirow[t]{2}{*}{ QuadroStim } & 41.0 & 50.6 & 39.9 \\
\hline & Skh1002A $\times$ Kh1012B & Skh1002A & Kh1012B \\
\hline Control & 45.7 & 33.8 & 35.7 \\
\hline FULVITAL Plus & 48.3 & 36.3 & 36.3 \\
\hline EcoStim & 48.0 & 36.5 & 37.2 \\
\hline \multirow[t]{2}{*}{ QuadroStim } & 46.9 & 32.6 & 39.9 \\
\hline & Skh808A/Kh1002B $\times$ Kh785V & Skh808A/Kh1002B & Kh785V \\
\hline Control & 47.0 & 48.9 & 43.2 \\
\hline FULVITAL Plus & 48.1 & 48.3 & 42.0 \\
\hline EcoStim & 47.8 & 47.1 & 43.3 \\
\hline \multirow[t]{2}{*}{ QuadroStim } & 48.4 & 50.6 & 43.0 \\
\hline & Skh1012A $\times$ Kh06135V & Skh1012A & Kh06135V \\
\hline Control & 41.8 & 40.9 & 39.0 \\
\hline FULVITAL Plus & 43.6 & 42.4 & 37.8 \\
\hline EcoStim & 41.6 & 41.1 & 38.5 \\
\hline \multirow[t]{2}{*}{ QuadroStim } & 42.6 & 40.6 & 39.9 \\
\hline & Skh808A $\times$ Shchelkunchyk & Skh808A & Shchelkunchyk \\
\hline Control & 50.7 & 51.3 & 44.0 \\
\hline FULVITAL Plus & 51.3 & 50.2 & 42.4 \\
\hline EcoStim & 48.8 & 51.0 & 42.9 \\
\hline QuadroStim & 50.8 & 51.4 & 42.4 \\
\hline $\mathrm{LSD}_{\mathrm{AB}}$ & 0.75 & 2.2 & 4.1 \\
\hline $\mathrm{LSD}_{\mathrm{A}}$ & 0.38 & 1.1 & 2.1 \\
\hline $\mathrm{LSD}_{\mathrm{B}}$ & 0.33 & 1.1 & 2.1 \\
\hline
\end{tabular}

${ }^{\star}$ Factor A, ${ }^{*}$ Factor B; Significant at $P<0.05$. 
the control) and in Skh808A/Kh1002B $\times$ Kh785V (47.8-48.4\% vs $47.0 \%$ in the control). The hybrid Skh1012A $\times$ Kh06135B increased the oil content in response to FULVITAL Plus by $1.8 \%$ (control $41.8 \%$ ). The parents mostly had the oil content similar to or below the control value, except for the line Skh1002A treated with FULVITAL Plus or EcoStim (36.3 or $36.5 \%$ vs $33.8 \%$ in the control) and line Kh1012B (36.3-39.9\%, depending on the growth regulator, vs $35.7 \%$ in the control). An increase in the oil content in seeds on average over the study years was observed in the female component of the simple hybrid Skh808A/ Kh1002B (50.6 vs $48.9 \%$ in the control).

It was noted that the growth regulators affected the oil content in hybrid seeds if one or both parents responded positively to the growth regulator treatment. Hybrid combinations responded more positively to the growth regulator treatment (in terms of the oil content) as a result of heterosis augmented by growth regulators, and a weak response of self-pollinating lines to the growth regulators can be attributed to severe inbred depression of the genotype.

Other researchers' field experiments with plant growth regulators containing similar active substances confirmed that the plant growth regulators were effective and that their effectiveness depended on the weather conditions (Ernst et al., 2016). In particular, Kagermazova et al. (2015) noted that the maximum accumulation of oil in sunflower seeds occurred when the air humidity was adequate and the soil contained enough water during the period from the anthesis to full maturity, so sufficient amounts of assimilants could be synthesized and a sufficiently large photosynthetic surface could be formed. The effectiveness of humic substances, fulvic acids and symbiotic fungi as agents improving the quality and productivity of seeds is described in the articles of Calvo et al. (2014).

\section{CONCLUSIONS}

1. Plant growth regulator FULVITAL Plus affects the yield and, depending on the studied genotype of sunflower, the oil content in seeds. In addition, it positively affects the 1000-seed weight and test weight in most of the genotypes under investigation.
2. Humic compound-based plant growth regulator QuadroStim affects the quality indicators, namely the 1000-seed weight and test weight, and this effect is most conspicuous in the female components of the hybrids.

3. The response of the sunflower genotypes to metabolites from the strain of a symbiotic endophyte fungus living on Panax ginseng $\mathrm{M}$. (EcoStim) was specific and varied depending on the genotype. It was noted that it was effective on the hybrids Skh808A/Kh1002B $\times$ Kh06135V, Skh1002A $\times$ Kh1012B and Skh808A/Kh1002B $\times$ $\mathrm{Kh} 785 \mathrm{~V}$, which showed the improved parameters (yield, 1000-seed weight, test weight of seeds and oil content). In general, the mechanism of action of such agents is still obscure, except for their important function of assisting the plant to fix nitrogen from the air.

4. Of the experimental hybrids, the heterosis effect was augmented in the three-line hybrid Skh808A/Kh1002B $\times$ Kh785V by all the tested growth regulators.

5. The genotype of a parent line was found to be important upon plant growth regulator application, since the response to a growth regulator could be inherited in hybrids.

Received 17 December 2020 Accepted 30 July 2021

\section{REFERENCES}

1. Abbadi J., Gerendas J. 2011. Effects of phosphorus supply on growth, yield, and yield components of safflower and sunflower. Journal of Plant Nutrition. Vol. 34. P. 1769-1787. Available at: https://doi.org/1 0.1080/01904167.2011.600405

2. Bernard R. G., Yoav B. 1997. Genetic manipulation of plant growth-promoting bacteria to enhance biocontrol of phytopathogens. Biotechnology Advances. Vol. 15. No. 2. P. 353-378. Available at: https://doi. org/10.1016/S0734-9750(97)00004-9

3. Calvo P., Nelson L., Kloepper J. W. 2014. Agricultural uses of plant biostimulants. Plant Soil. Vol. 383. P. 3-41. Available at: https://doi.org/10.1007/ s11104-014-2131-8

4. Davies P. J. 2010. The plant hormones: their nature, occurrence, and functions. Plant Hormones. P. 1-15. Available at: https://doi.org/10.1007/978-14020-2686-7_1

5. Dehodiuk E. H., Vitvitska O. I., Dehodiuk T. S. 2014. Modern approaches to the optimization of mineral nutrition of plants in organic farming. Collection 
of Scientific Works of NSC Institute of Agriculture NAAS'. No. 1-2. P. 33-39 (in Ukrainian).

6. Ermantraut E. R., Hoptsii T. I., Kalenska S. M., Kryvoruchenko R. V., Turchynova N. P., Prysiazhniuk O. I. 2014. Methods of Breeding Experiments (in Plant Production). KhNAU nd. A VV Dokuchaev. 229 p. (in Ukrainian).

7. Ernst D., Kovar M., Černý I. 2016. Effect of two different plant growth regulators on production traits of sunflower. Journal of Central European Agriculture. Vol. 17. No. 4. P. 998-1012. Available at: https://doi.org/10.5513/JCEA01/17.4.1804

8. Geetha T., Murugan N. 2017. Plant growth regulators in mulberry. Annual Research \& Review in Biology. Vol. 13. No. 3. P. 1-11. Available at: https:// doi.org/10.9734/ARRB/2017/29637

9. Grabovsky M. B. 2010. Influence of plant density on the manifestation of economically valuable traits and productivity of sunflower in the conditions of the central Forest-Steppe of Ukraine. Bulletin of the Institute of Grain Management of UAAS. Vol. 38. P. 88-91 (in Ukrainian).

10. Gruznova K. A., Bashmakov D. I., Miliauskienė J., Vaštakaitė V., Duchovskis P., Lukatkin A. S. 2018. The effect of a growth regulator Ribav-Extra on winter wheat seedlings exposed to heavy metals. Žemdirbystè-Agriculture. Vol. 105. No. 3. P. 227-234. Available at: https://doi.org/10.13080/za.2018.105.029

11. Gustafsson A. 1946. The effect of heterozygosity on variability and vigour. Hereditas. Vol. 32. No. 2. P. 263-286. Available at: https://doi. org/10.1111/j.1601-5223.1946.tb02779.x

12. Hoptsii T. I. 2003. Genetic and Statistical Methods in Breeding. Kharkiv: KhNAU nd. A VV Dokuchaev. 103 p. (in Ukrainian).

13. Iqbal J., Irshad J., Bashir S., Khan S., Yousaf M., Shah A. N. 2019. Comparative study of water extracts of Moringa leaves and roots to improve the growth and yield of sunflower. South African Journal of Botany. Vol. 129. P. 221-224. Available at: https://doi.org/10.1016/j.sajb.2019.06.032

14. Jung J., Rademacher W. 2018. Plant growth regulating chemicals - cereal grains. In: Plant Growth Regulating Chemicals. Vol. 2. CRC Press. P. 253-271.

15. Kagermazova A. Ch., Kurashev Zh. Kh., Gadieva A. A., Kertova M. M. 2015. Influence of water security of plants and quality of sunflower seed varieties on oil yield. Modern Problems of Science and Education. Vol. 1. No. 1. P. 1694-1694 (in Russian).

16. Knapowski T., Szczepanek M., Wilczewski E., Pobereżny J. 2015. Response of wheat to seed dressing with humus and foliar potassium fertilization. Journal of Agricultural Science and Technology. Vol. 17. No. 6. P. 1559-1569.

17. Lippman Z. B., Zamir D. 2007. Heterosis: revisiting the magic. Trends in Genetics. Vol. 23. No. 2.
P. 60-66. Available at: https://doi.org/10.1016/j. tig.2006.12.006

18. Lucy M., Reed E., Glick B. R. 2004. Applications of free living plant growth-promoting rhizobacteria. Antonie van leeuwenhoek. Vol. 86. No. 1. P. 1-25.

19. Lynch M. 1997. Inbreeding depression and outbreeding depression. Genetic Effects of Straying of Non-native Hatchery Fish into Natural Populations: Proceedings of the Workshop. Seattle, Washington. Vol. 30. P. 59-67.

20. Marenych M. M., Yurchenko S. O., Bahan A. V., Yeshchenko V. M. 2018. Performance of winter wheat varieties influenced by humic substances. Visnyk Poltavskoi Derzhavnoi Ahrarnoi Akademii. Vol. 1. P. 63-66. Available at: https://doi. org/10.31210/visnyk2018.01.09 (in Ukrainian).

21. Matvienko A. F. 1992. On the selection of sunflower biotypes attractable for bees. Selektsiya $i$ Semenovodstvo. Vol. 2. No. 3. P. 14-16 (in Russian).

22. Ousley M. A., Lynch J. M., Whipps J. M. 1994. Potential of Trichoderma spp. as consistent plant growth stimulators. Biology and Fertility of Soils. Vol. 17. No. 2. P. 85-90. Available at: https://doi. org/10.1007/BF00337738

23. Patrick S., Nathan M. 2013. Progress toward understanding heterosis in crop plants. Annual Review of Plant Biology. Vol. 64. P. 71-78. Available at: https:// doi.org/10.1146/annurev-arplant-042110-103827

24. Petibskaya V. S. 1993. Influence of meteorological conditions on the sunflower oil quality. Izvestiya Vysshykh Uchebnykh Zavedeniy. Pishchevaya Tekhnologiya. Vol. 1. No. 2. P. 32-34 (in Russian).

25. Shapoval O. A., Mozharova I. P., Korshunov A. A. 2014. Plant growth regulators in agricultural technologies. Plant Protection and Quarantine. Vol. 6. P. 16-20 (in Russian).

26. Škorić D., Seiler G. J., Zhao L., Chao-Chien J., Miller J. F., Charlet L. D. 2015. Sunflower Genetics and Breeding. Serbian Academy of Sciences and Arts, Association 'Sunflower Breeding and Seed Production'. $520 \mathrm{p}$.

27. Skvortsov I. V.2006. Performance of inbred sunflower lines. Collection of Scientific Works of the National Centre 'Institute of Agriculture of UAAS'. Vol. 4. P. 102-106 (in Ukrainian).

28. Special Breeding and Seed Production of Field Crops (ed. V. V. Kyrychenko). 2010. PPI nd. a VYa Yuriev NAAS Ukraine. 462 p. (in Ukrainian).

29. Sunflower (Helianthus annuus L.) Breeding and Seed Production. 2005. Kyrychenko V. V. PPI nd. a VYa Yuriev NAAS Ukraine. 385 p. (in Ukrainian).

30. Szweykowska A. 1997. Fizjologia Roślin. Wyd. Naukowe UAM. 250 ss. (in Polish). Available at: https://doi.org/10.1007/978-1-4020-2686-7_1

31. Upreti K., Maryada S. 2016. Role of plant growth regulators in abiotic stress tolerance. Abiotic Stress Physiology of Horticultural Crops. P. 19-46. Available at: https://doi.org/10.1007/978-81-322-2725-0_2 


\section{Dmytro Chuiko}

\section{AUGALŲ AUGIMO REGULIATORIAUS ITAKA SAULĖGRĄŽOMS IR JŲ F1 HIBRIDAMS}

Santrauka

Norint padidinti auginamų saulègrąžų produktyvumą ir augalų atsparumą stresui reikia ieškoti naujų šių augalų auginimo metodų bei tobulinti esamas technologijas. Žemas saulègrąžų sèklų produktyvumas skatina išvesti naujas šių augalų hibridines veisles.

Tyrimo tikslas - j̇vertinti savidulkių saulègrąžų, skirtų veisimui ir sėklų auginimui, bei F1 hibridų, kurie buvo sukurti sukryžminus šias dvi augalų linijas, individualų atsaką $\mathfrak{i}$ augalų augimo reguliatorius. Buvo nustatyta, kad hibridinès linijos dèl augimo reguliatorių ịtakos pasižymèjo geresniais derliaus rodikliais ir didesniu aliejaus kiekiu, palyginti su linijomis, pagrịstomis normalia citoplazma. Augalų augimo reguliatoriai padidino heterozès efektą eksperimentiniuose hibriduose. Geriausias atsakas buvo pastebètas trijų eilučių hibridiniame Skh808A / Kh1002B × Kh785V pagal visus tirtus parametrus. Augimo reguliatoriai sustiprino koreliaciją tarp 1000 sèklų svorio ir derlingumo $(r=0,51-0,97)$. Aliejaus kiekis F1 hibridų sẻklose priklausè nuo genotipo ir galejo būti palyginamas tiek su pirminiu, turinčiu mažai aliejaus, tiek su daug aliejaus turinčiu pagrindu. Aliejaus kiekio svyravimai sẻklose priklausė nuo augimo reguliatoriaus tipo ir dirvožemio / klimato sąlygų sẻklų formavimosi metu.

Raktažodžiai: veislių išvedimas, hibridai, linijos, augalų augimo reguliatoriai, sėklų auginimas, saulègrąžos 